\title{
Pilot study on the influence of stress caused by the need to combine work and family on occupational accidents in working women
}

\author{
Susana Martín-Fernández ， Ignacio de los Ríos , Adolfo Cazorla , Eugenio Martínez-Falero \\ Department of Forestry Economy and Management, Technical University of Madrid, Escuela Técnica Superior de Ingenieros de Montes, Ciudad Universitaria sn, 28040 Madrid, Spain \\ Department of Projects and Rural Planning, Escuela Técnica Superior de Ingenieros Agrónomos, Technical University of Madrid, Ciudad Universitaria sn, 28040 Madrid, Spain
}

Keywords:

Occupational accident

Work

Family

Stress

Women

\begin{abstract}
A B S T R A C T
The influx of a large number of women into the workforce involves the need for these women to combine family and work responsibilities. Multiple roles lead to work-family conflict. This study analyzes the influence of work-family conflict on the causes of minor occupational accidents suffered by working women. A survey was done on working women in the Madrid region, who had suffered a minor occupational accident in 2004. The main finding was that nearly half of the women with children considered that the stress and fatigue caused by trying to combine work and family played a part in the accident; $21 \%$ of the respondents whose accidents took place while traveling to or from work and $11 \%$ the respondents who suffered the accident in the workplace said that family reasons played a part. Additionally, $50 \%$ of the women suffered after-effects as a result of the accident; children had to change their routine in almost 1 in 4 cases; nearly a quarter of the respondents said their work situation had been temporarily modified. This point to a need for polices that encourage men and employers to contribute more to solve work-family conflicts.
\end{abstract}

\section{Introduction}

The multiple role pressures experienced by women and men make work-family conflict virtually inevitable (Burke, 1988; Greenhaus, 1988). Grandey and Cropanzano (1999) defined work-family conflict as a perception of insufficient energy and/or time to perform both work and family roles successfully. Workrelated and non-work-related factors associated with work-family conflict have been amply studied (Geurts et al., 1999; Greenhaus and Kopelman, 1981; Jansen et al., 2003; Pleck et al., 1980), as well as the consequences associated with work-family conflict, such as job dissatisfaction, job burnout, stress, depression and life dissatisfaction among others (Allen et al., 2000; Lundberg and Frankenhaeuser, 1999).

Working women still have a greater psychological and behavioral involvement in family work than men, and are primarily responsible for the children and household to a greater degree than their partners (Conde and Gabriel, 2002; Greenhaus and Parasuraman, 1999; Lewis and Cooper, 1999; Swanson, 2000). Twenty-five percent of European women over 18 are involved in childcare every day, as compared to $9 \%$ of men (Instituto Nacional de
Estadística, 2007). This lack of support by men is basically due to cultural reasons. This tendency is more pronounced in Mediterranean countries (European Commission, 2006; Kauppinene and Irja, 1998). A worldwide study of 30,000 people in 30 countries carried out in 1999 by the consulting company Roper Starch Worldwide showed a high level of stress in women who work full-time and have children under 13; in fact this is the most highly-stressed group of all those in employment, (Biscay, 1999).

In Europe, the influx of large numbers of women into the workforce in recent decades has meant that health and safety policies at work have had to take into account occupational illnesses and work-related risks specifically affecting women. Community strategy on health and safety at work (2002-2006) acknowledges the specific requirements of women in matters of work safety and recommends that these gender-related aspects should therefore be integrated into the legislation and into company organization. Efforts should also be made to improve ergonomics in the workplace, so as to recognize physiological and psychological differences between the sexes, and to address gender-related aspects of risk evaluation, preventive measures and compensation (European Commission, 2002).

The combination of unsafe behavior, unsafe conditions and the risk inherent in the activity may lead to work-related accidents (Petersen, 1984), and these risks may be further aggravated by emotional stress and psychosocial factors (Kirschenbaum et al., 2000; Li et al., 1999; Swaen et al., 2004). Several studies carried 
out in the 1990 s show that $26-40 \%$ of workers report high levels of stress in the workplace (Bond et al., 1997; Conde and Gabriel, 2002; Galinsky et al., 1993; Reich and Nussbaum, 1994; Swanson, 2000). Conflicts between work and family roles and gender-specific stressors are considered job stressors (Hurrell and Murphy, 1992; Martín et al., 2004; Sauter and Swanson, 1996).

Approximately $20 \%$ of the accidents incurring injury leave in the European Union occur in Spain. This rate is twice the Eurozone average in the manufacturing, construction and transport, storage and communication sectors, although there has been a downward trend since 1999 (Eurostat, 2005). Until 1999, when the authorities changed the law regulating work-related accidents, there was a suspicion of under-reporting. Under the new legislation, employers have to pay the first 15 days of absence from work when this is due to common illness, while insurance companies are still responsible for compensating absence due to accidents. As a consequence, more accidents are now being reported which were previously being compensated as "illnesses" (Attwood et al., 2006).

The considerable differences existing among the EU countries regarding the gathering of information on work accidents led Eurostat (Statistics Office of the European Union) in cooperation with EU member states, to develop in 1990 the ESAW project (European Statistics on Accidents at Work), in order to collect comparable data on accidents and to establish a database (European Agency for Safety and Health at Work, 2000). However, even today there are several differences in criteria between the proposals in the ESAW project and Spanish legislation (Ministerial Order TAS/ 2926/2002):

1. According to ESAW, an accident at work is defined as a "discrete occurrence in the course of work, which leads to physical or mental harm"; the definition also includes accidents occurring during work but off the company's premises (i.e. in transit, public places). The current definition of Spanish legislation is "All bodily injury suffered by any worker employed by a third party in the course of, or as a result of, his or her work, both while traveling from home to the workplace and vice versa (in itinere), and in the workplace itself". Spanish legislation therefore considers commuting accidents to be work accidents, as occurs in Belgium, Austria, and Portugal (Jacinto and Aspinwall, 2004).

2. ESAW statistics are based on the criterion of more than 3 days' absence from work for non-fatal accidents; Spanish statistics are based on one day's absence from work.

3. Regarding the severity of the injury, Spain recognizes four degrees: minor, serious, very serious and fatal. The degree of severity assigned to the accident in the corresponding report must coincide with the evaluation in the medical report completed by the doctor who attended the injured worker, and is not related to the length of the person's leave period.

Act $31 / 95$ of 8 November, 1995, regarding risk prevention at work, transferred the functions and services of the Spanish Central Administration to the Autonomous Governments of each region, who were granted executive and management powers in matters of health and safety at work as of January 1996. In the Madrid region, the work accident rate was 3985 per 10,000 people per year, very near the national average (Instituto Nacional de Estadística, 2005a). The Madrid region has one of the highest GDP at current prices in the whole of Spain (Instituto Nacional de Estadística, 2006). Among the 17 autonomous regions, the figure for active population in the Madrid region was 2,705,525 people in 2004, the highest in the country together with Andalusia and Catalonia. The Madrid region has the highest employment rate in Spain for both women and men, with figures of $61 \%$ and $79 \%$, respectively. Of the active population, $1 \%$ work in agriculture, $13 \%$ in industry, $12 \%$ in construction and $74 \%$ in the service sector (Instituto Nacion- al de Estadística, 2005). Finally, the figure corresponding to women under 50 occupied with their children was 5200 out of every 10,000 people in 1999 (Instituto Nacional de Estadística, 1999).

The aim of the study was to analyze, by means of a participative process, the importance of work-family conflict in the factors involved in minor work-related accidents, and to determine how these accidents subsequently affected the subjects' families and work.

\section{Method}

In the European Union, the regulations contained in Directive $89 / 391 / E E C$ introducing measures to encourage improvements in the health and safety of workers at work, highlighted the need to harmonize the data on work accidents. In order to achieve this goal, the European Statistics on Accidents at Work project was set up in 1990, and coordinated by the Commission's Directorate General of Employment and Social Affairs, and by the Statistics Office of the European Union (EUROSTAT) (European Agency for Safety and Health at Work, 2000). Order TAS/2926/2002 approved the new models for reporting work accidents, as well as the Electronic Accident Declaration System (Delt@). This system came into service in Spain at the end of 2003. In the Madrid region, according to this order, the Regional Institute of Health and Safety at Work, IRSST, is authorized to access and operate the database for this area. Our study began with a survey of a random sample of women in the Madrid region who had suffered a minor work accident in 2004. Under Act 15/1999 of 13 December on Personal Data Protection, the survey had to be anonymous (i.e. we did not know respondents' names, ID numbers or exact address). The survey was conducted by post, by the IRSST. Respondents could either fill in the questionnaire and return it, or call anonymously one of the telephone numbers provided in the questionnaire if they preferred to answer by phone. The survey was conducted in September and October 2005. Once the question period was finished, the answers were purged and analyzed, and the relation between some of the indicators was studied using $\chi^{2}$ independence tests.

\subsection{Sample size and sampling errors}

The population sample was taken from the total reports of women who had suffered a minor work accident in the Madrid region in 2004, and were recorded in the Delta system. The size of the population was 34,404 women. The sample was taken at random with the Statgraphics 5.1 program, and the erroneous or incomplete data were purged. The final size of the sample was 2400 women.

The error was calculated for each question. The expression of the error was as follows:

$d=\sigma_{p} Z \alpha / 2$

where $Z \alpha / 2$ is the fractal of normal distribution associated to the significance level $\alpha / 2$.

$\sigma_{p}$ is the standard deviation, whose expression is as follows:

$\sigma_{p}=\sqrt{\frac{p q}{n} \frac{(N-n)}{N-1}}$

where $p$ is the proportion of answers analyzed, $q$ the proportion of other answers, $N$ is the population size and $n$ the size of the sample.

\subsection{Description of the questionnaire}

The questionnaire, which can be consulted on Internet, was divided into five sections with questions designed to describe the respondent, her household responsibilities, work situation and 
the causes and consequences of the accident. These sections were the following:

1. Personal characteristics of the women questioned The main aim of the questions in this section was to obtain an objective classification of the respondent by compiling data on her age, educational level, professional characteristics, marital status and household responsibilities at the time of the accident.

2. Family-work interrelation

To determine the parameters affecting levels of stress and fatigue, in this section the subject was asked whether during the workday her family duties interfered with her work and vice versa, and whether her work activity extended into her time at home after the end of the working day.

3. Opinion of the respondents on their work situation before the accident

This part of the survey was designed to measure the degree of satisfaction of the women with their work, not only with their actual functions at work, but also with the atmosphere in the workplace, as well as with the facilities provided by their employers to assist in combining work and family.

4. Personal opinion of the accident

This group of questions focused on the accident itself. It was designed to determine what the women subjectively considered to be the cause of the accident, and whether the stress and fatigue accumulated by combining work and family (if this were the case) had played a part in causing the accident.

5. Consequences of the accident on the subject's family and work This last section was intended to ascertain whether these accidents classified as "minor" could be serious enough subsequently to affect family life and/or work. To determine this, the women were asked if they had suffered any after-effects as a result of the accident, and if they had observed any repercussions on the family or their work.

Finally, the respondent was able to add any comment related with the topics in the questionnaire.

\section{Results}

\subsection{Accuracy and representativity of the sampling}

The questionnaire was sent to 2400 people. At the end of the data collection phase, the number of questionnaires returned was $13 \%$, although some respondents had omitted to answer whole sections of questions. $94 \%$ of the questions had a sampling error of less than $7 \%$, and the most common error was $5 \%$. These errors are acceptable from the statistical point of view, and therefore the size of the sample was not increased.

As the percentage of the questionnaires answered was $13 \%$, we analyzed the representativity of the sample. To do so, we compared sample values for the type of injury variable, according to the classification of the Ministry of Work and Social Affairs (Ministerio de Trabajo y Asuntos Sociales, 2004) with the population values for minor accident reports in 2004 in the Delta data base (Table 1).

The distribution of injury types is very similar in the women who answered the questionnaire and the population; in both cases, more than half the injuries were dislocations and sprains, followed by superficial wounds and injuries, in 21 and $23 \%$ of cases respectively. Other data that were also compared with population data to verify the representativity of the sample were the number of children for working women up to the age of 49 . The National Fertility Survey of 1999 (Instituto Nacional de Estadística, 1999) shows that $52 \%$ of working women under 49 had children, a figure that coin-
Table 1

Percentage of respondents, and population percentages for women's minor workrelated accident reports in 2004 , according to type of injury

\begin{tabular}{lcc}
\hline Type of injury & $\begin{array}{c}\% \text { of } \\
\text { respondents }\end{array}$ & $\begin{array}{c}\% \text { of } \\
\text { population }\end{array}$ \\
\hline 00 - Unknown injury & 1 & 1 \\
01 - Superficial wounds and injuries & 21 & 23 \\
02 - Fractures & 10 & 5 \\
03 - Dislocations and sprains & 51 & 58 \\
05 - Concussion and internal injuries & 6 & 6 \\
06 - Burns, scalds and frostbite & 1 & 1 \\
09 - Effects of noise, vibration and pressure & 1 & 0 \\
11 - Shock & 1 & 1 \\
12 - Multiple injuries & 3 & 2 \\
99 - Other specified injuries not included in other & 5 & 3 \\
categories & & \\
\hline
\end{tabular}

cides with the proportion of women under 50 who answered the questionnaire. In view of these results, we considered the sample to be representative of the population.

\subsection{Results of the survey}

\subsubsection{Personal characteristics of the women questioned}

Table 2 shows a summary of the personal characteristics of the women questioned.

Of the 308 women questioned, $57 \%$ were living with their partners when the accident occurred. The work situation of the partners was on the whole stable; $76 \%$ were in permanent employment, $20 \%$ in temporary employment and only $4 \%$ were unemployed. Fifty-eight percent of the women had children in their charge; of this number, $94 \%$ had one to three children, and $6 \%$ had more than three. In $31 \%$ of cases, the youngest child was 18 or over; in $28 \%$ the youngest child was between 12 and 18 ; in $25 \%$, between 5 and 12 , and in $16 \%$, between 0 and 4 . Therefore a large majority of children (69\%) were under 18 , and $41 \%$ were under 11 ; at this age children are very dependent on other people. Ten percent of the respondents had disabled persons under their

Table 2

Personal characteristics of the women questioned

\begin{tabular}{|c|c|c|}
\hline Parameter & & $\begin{array}{l}\text { Percentage } \\
\text { of women } \\
\text { questioned }\end{array}$ \\
\hline Age & $\begin{array}{l}<26 \\
26-40 \\
41-55 \\
>55\end{array}$ & $\begin{array}{l}11 \\
47 \\
35 \\
7\end{array}$ \\
\hline Marital status & $\begin{array}{l}\text { Living with partner } \\
\text { Single } \\
\text { Separated or divorced }\end{array}$ & $\begin{array}{l}57 \\
30 \\
13\end{array}$ \\
\hline Number of children & $\begin{array}{l}\text { None } \\
1-3 \\
\text { More than } 3\end{array}$ & $\begin{array}{l}42 \\
54 \\
4\end{array}$ \\
\hline Nationality & $\begin{array}{l}\text { Spanish } \\
\text { Foreign }\end{array}$ & $\begin{array}{l}95 \\
5\end{array}$ \\
\hline Educational level & $\begin{array}{l}\text { Primary school (up to six years' education) } \\
\text { Secondary school or professional degree } \\
\text { ( } 12 \text { years of education) } \\
\text { University degree }\end{array}$ & $\begin{array}{l}22 \\
51 \\
27\end{array}$ \\
\hline Place of residence & $\begin{array}{l}\text { Madrid (city) } \\
\text { Madrid region }\end{array}$ & $\begin{array}{l}44 \\
56\end{array}$ \\
\hline Place of work & $\begin{array}{l}\text { Madrid (capital) } \\
\text { Madrid region }\end{array}$ & $\begin{array}{l}38 \\
62\end{array}$ \\
\hline Working hours & $\begin{array}{l}\text { Part-time job (up to } 25 \text { h per week) } \\
\text { Full-time job ( } 35-40 \text { her week) }\end{array}$ & $\begin{array}{l}5 \\
95\end{array}$ \\
\hline
\end{tabular}


Table 3

Distribution of occupations of the women in the survey according to the 2000 Standard Occupational Classification System (U.S. Department of Labor, 2004)

\begin{tabular}{lc}
\hline Main groups & \% of women \\
& questioned \\
\hline Management occupations & 5 \\
Computer and mathematical occupations & 2 \\
Architecture and engineering occupations & $<$ \\
Education, training and library occupations & 1 \\
Art, design, entertainment, sports, and media occupations & 1 \\
Healthcare practitioners and technical occupations & 2 \\
Healthcare support occupations & 10 \\
Protective service occupations & $<1$ \\
Food preparation and service related occupations & 9 \\
Building and grounds cleaning and maintenance occupations & 16 \\
Personal care and service occupations & 6 \\
Sales and related occupations & 15 \\
Office and administrative support occupations & 24 \\
Construction and extraction occupations & 1 \\
Production occupations & 5 \\
Transportation and material moving occupations & 2 \\
\hline
\end{tabular}

charge, and all these women also had children. However, only $21 \%$ of the women who answered the questionnaire (15\% with children, $6 \%$ without) had any help in the home (i.e. a family member, domestic help, or a child minder).

of the 308 women questioned, $95 \%$ had full-time jobs; $94 \%$ worked in the service sector, $5 \%$ in industry, and $1 \%$ in construction. Seventy-eight percent of the respondents had at least a secondary education. Table 3 shows the distribution of the occupations according to the U.S. Department of Labor Classification (2004).

In $61 \%$ of cases, the respondents belonged to the white-collar sector, basically administrative, and $39 \%$ to the blue-collar sector. Regarding their work situation; $23 \%$ had temporary contracts and the rest had permanent contracts.

\subsubsection{Family-work interrelation}

Forty-two percent of the respondents did not work in the same district as their home, and their travel time was over $45 \mathrm{~min}$ in $50 \%$ of the cases. Only $15 \%$ walked to their place of work, while the remainder took public or private transport. Forty-two percent of the respondents said that before arriving at work they carried out family-related activities during these travel periods. Finally, $39 \%$ answered that after work, but before arriving home, they performed family-related activities such as shopping and collecting children from school or from other activities. Almost a quarter of the women (22\%) performed family-related tasks during rest periods in their work schedule.

\subsubsection{Opinion of the respondents on their work situation before the accident}

Forty-three percent of the respondents did not find their work fulfilling, and up to $31 \%$ were not happy in their job. Forty-one percent perceived the atmosphere at work as negative. These results were independent of the economic sector ( $p$-value 0.6) and education ( $p$-value 0.1 ) of the respondents. Regarding the interference of work in home life, the majority of the women said that they never took work home; only $4 \%$ did so, and all of these had a university degree. However, they encountered serious difficulties in combining work and family. As many as $74 \%$ said that they had no flexibility in their schedules, while $48 \%$ answered that no facilities were provided by their employers to attend to family matters. These results were independent of the economic sector ( $p$-value 0.7 ) and education ( $p$-value 0.8 ) of the respondents.

To measure how large a percentage of occupational stress is due to strain caused by combining work and family, we studied the variables for flexibility in the schedule, the need to attend to family matters during the workday, and availability of domestic help or
Table 4

Respondents' answers according to work-family conflict indicators

\begin{tabular}{lllcc}
\hline $\begin{array}{l}\text { Attend } \\
\text { to family }\end{array}$ & $\begin{array}{l}\text { Flexible } \\
\text { schedule }\end{array}$ & $\begin{array}{l}\text { Help in } \\
\text { home }\end{array}$ & $\begin{array}{l}\text { \% of total } \\
\text { respondents }\end{array}$ & $\begin{array}{l}\text { \% of total respondents that } \\
\text { connected family life to accident }\end{array}$ \\
\hline $\mathrm{n}$ & $\mathrm{y}$ & $\mathrm{n}$ & 6 & 1 \\
$\mathrm{n}$ & $\mathrm{n}$ & $\mathrm{y}$ & 4 & 1 \\
$\mathrm{n}$ & $\mathrm{n}$ & $\mathrm{n}$ & 4 & 1 \\
$\mathrm{y}$ & $\mathrm{y}$ & $\mathrm{n}$ & 5 & 1 \\
$\mathrm{y}$ & $\mathrm{n}$ & $\mathrm{y}$ & 13 & 3 \\
$\mathrm{y}$ & $\mathrm{n}$ & $\mathrm{n}$ & 25 & 15 \\
$\mathrm{y}$ & $\mathrm{y}$ & $\mathrm{y}$ & 1 & 1 \\
\hline
\end{tabular}

childcare in the home. Table 4 shows the percentages of the answers to these variables by the total of respondents who had at least one child.

$44 \%$ of these respondents potentially suffered family strain.

\subsubsection{Personal opinion of the accident}

We began the analysis by verifying whether the perception of the work situation might be affected by the accident. The following $\chi^{2}$ independence contrasts were done between the qualitative variables describing the opinion of work (Did you feel fulfilled by your work? (yes, no); Was there a good atmosphere in your place of work? (yes, no); Were you satisfied with the tasks you were given to do? (yes, no)) as compared to the work-related consequences of the accident. (Has the position you held changed since the accident? (yes, no); Do you suffer from any after-effects of the accident? (yes, no)). Of the six independence contrasts, there is only one statistically significant relation between the perception of the working environment and the after-effects of the accident ( $p$ value 0.02). However, those women who suffered after-effects were those with the best opinion of their work. This can be explained by the fact that $87 \%$ of this subset of respondents had been satisfied with the position they held before the accident, and after the accident, $73 \%$ continued in the same position.

Sixty-six percent of those questioned suffered their accidents in the workplace, while the remaining $34 \%$ occurred traveling to or from work. Regarding the aspects that played a part in the accident, $23 \%$ considered that family preoccupations could be connected to the accident. Only $4 \%$ said that the accident was solely due to family-related reasons. Another finding was that $18 \%$ considered that their family life was responsible for diminished performance at work at certain times, and this percentage indicates that the demands of home life may have a negative effect on work-related risks (Kirschenbaum et al., 2000)

We analyzed the potential stress suffered by the respondents who considered that work-family conflict played a part in the accident. Results are shown in Table 4. Twenty percent of the total respondents, and $87 \%$ of those who considered that family preoccupations could be connected to the accident, potentially suffered family strain.

3.2.5. Consequences of the accident on the subject's family and work Regarding the repercussions of the accident on the family, $67 \%$ required extra home help after the accident, although in $14 \%$ of cases this help came from the women's partners, who requested a temporary modification of their work schedules. As regards their children, almost 1 in 4 (24\%) had to change their routine or live temporarily in the home of other family members while their mother was recovering. Fourteen percent of the women had to ask for financial assistance in order to cover their household duties after the accident and throughout the time they were off work.

Another analysis of the consequences of the accidents on the family during the leave period was done by grouping the women 
Table 5

Length of leave taken by the respondents

\begin{tabular}{lc}
\hline Length of leave (days) & \% of women questioned \\
\hline $0-6$ & 7 \\
$7-14$ & 21 \\
$15-21$ & 16 \\
$22-30$ & 18 \\
$31-61$ & 16 \\
$62-179$ & 14 \\
$>179$ & 8 \\
\hline
\end{tabular}

Table 6

Respondents' comments on the topics in the survey

\begin{tabular}{|c|c|}
\hline Comment & Percentage \\
\hline $\begin{array}{l}\text { Balancing family life: } \\
\text { - Need for flexible work schedule: } 14 \% \\
\text { - Assistance for women (crèches, childcare subsidies, involvement } \\
\text { by employers, etc.): } 14 \%\end{array}$ & 28 \\
\hline Reason for accident & 6 \\
\hline Request for financial help during the leave period: & 5 \\
\hline Lack of time to recover from the accident: & 10 \\
\hline $\begin{array}{l}\text { Negative repercussions in the workplace on returning to work after } \\
\text { leave period: (dismissal, non-renewal of contract, lack of help from } \\
\text { employers, etc.) }\end{array}$ & 12 \\
\hline $\begin{array}{l}\text { Poor work organization: } \\
\text { - Staff shortages: } 3 \% \\
\text { - Lack of work security: } 10 \% \\
\text { - Lack of training: } 1 \% \\
\text { - Excessive workload: } 8 \%\end{array}$ & 22 \\
\hline $\begin{array}{l}\text { Disagreeable work environment: (harassment, inequality between } \\
\text { men/women) }\end{array}$ & 10 \\
\hline Other comments & 7 \\
\hline
\end{tabular}

according to the place of the accident (travelling to and from work vs at work) and work-family strain (yes vs no). However, in the case of $30 \%$ of the respondents with work-family strain, in both the group of women who suffered the accident in itinere and in the group who had their accident at work, their partners had to modify their work situation, compared to $13 \%$ in the groups without work-family strain.

In the case of children, $71 \%$ of the women in the group who had their accident in itinere and suffered work-family strain had to modify their daily routine, compared to $29 \%$ in the other groups.

Regarding length of leave period, Table 5 shows that $38 \%$ of the women were off work for at least one month.

Most of the respondents (57\%) said that they considered the time off to be insufficient for their recovery. Of this number, $89 \%$ were still suffering after-effects when the survey was carried out. Among those who considered the time off to be sufficient, $42 \%$ also still suffered after-effects. These after-effects temporarily hindered their working activities, and $22 \%$ of those questioned maintained that their work situation - either the position they held or the duties they were expected to perform at work - had been temporarily modified as a result of the accident. Nine percent of the women received some kind of specific help for their situation from their employers.

The questionnaire ended with an opportunity for the respondents to add any comments they wanted. Table 6 shows these comments grouped into themes.

\section{Discussion}

This article has attempted to analyze how far work-family conflict can be considered to be among the psychosocial factors that play a role in minor work-related accidents, based on the opinion of women who have suffered such an accident.

Only $13 \%$ of the women selected for the questionnaire responded, and therefore an analysis was made of the representativ- ity of the respondents (Cea, 2001); we used a representative variable for "type of injury", and the results demonstrated that the sample could be considered representative.

Another possible problem was that the number of women who answered that their family life played a part in the accident might be higher than the actual figure, as the respondents were aware of the objectives of the questionnaire. However, the answers showed that only $4 \%$ considered that the only cause of the accident was the work-family conflict, and the respondents' comments indicate that their main preoccupation was how to successfully combine their work with their family life (flexible work schedules, involvement by the employer, etc.) (28\%), their situation at work (32\%), and to a lesser degree the accident itself (10\%). We therefore feel confident that the percentage of women who consider that they were under stress arising from family causes has not been overestimated.

Factors that determine the occurrence of the work-family conflict are schedule, domestic help, the presence of children at home, commuting time to and from work (Geurts et al., 1999; Greenhaus and Kopelman, 1981; Jansen et al., 2003; Pleck et al., 1980). Therefore, the variables used to determine the existence of work-family strain were the need to attend to family matters during the workday, flexible work schedule, the presence of children and domestic help in the home.

The work-family conflict was analyzed in combination with lack of job satisfaction, as these two stressors could both increase the risk of accidents (Swaen et al., 2003). What is more, there is a statistically significant relationship between job satisfaction and the variable "need to attend family matters" ( $p$-value 0.0033 ) and job satisfaction and flexible schedule, ( $p$-value $<0.0001)$. In the case of work, employees who view the organization as involved in a positive social exchange will have a more positive attitude toward the organization (Lankau, 1997; Robinson et al., 1994). Additionally, the availability of workplace supports and organizational work-family culture also uniquely predicts job satisfaction (Kirschenbaum et al., 2000), but long working hours for employed women with children are linked to higher stress and lower job satisfaction (Allen et al., 2000; Kauppinene and Irja, 1998; Jansen et al., 2003; Lundberg and Frankenhaeuser, 1999). Women who considered that family life affected their work (23\% of total respondents) generally bore more family responsibilities. Within this group, $11 \%$ of total respondents considered that their situation at work was satisfactory; most were subjected to work-family strain, which might increase the risk of work-related accidents (Kirschenbaum et al., 2000; Li et al., 1999; Swaen et al., 2004). Another subgroup ( $10 \%$ of respondents), in addition to potentially undergoing work-family conflict, were dissatisfied with their situation at work.. This is shown not only by the answers to the questionnaire, but also in the comments at the end, where $28 \%$ wanted more support by the employers.

To judge by the answers, there is a statistically significant relationship between the perception of the factors connected to the accident and the need to attend to family demands ( $p$-value 0.0108 ). Eighty-seven percent of the respondents who considered that work-family conflict played a part in the accident had to attend to family matters. However, $24 \%$ of respondents had potentially the same level of work-family strain as this group, but did not consider that this stress played a part in the accident; in $62 \%$ of cases they considered that the accident was due to work, and the rest to non-specified or physical causes. Finally, 5\% of respondents potentially did not have stress for family reasons, but were under pressure at work. The rest of the respondents potentially did not have stress either at work or from their family life - and this group included $5 \%$ of women with children. These respondents considered that the causes of the accident were either their work or unspecified causes. 
Regarding the location of the accident, there is a statistically significant relationship between the perception that the workfamily conflict was a factor in the accident and the place of the accident (in the workplace or traveling to or from work) ( $p$-value $<0.001$ ). Twenty-one percent of the respondents whose accidents took place while traveling to or from work and $11 \%$ of the respondents who suffered the accident in the workplace said that family reasons played a part.

There are other well-documented risk factors for work accidents, such as age (Alhaique, 2000; Islam et al., 2001; Laflamme and Menckel, 1995; Salminen, 2004); young workers are less experienced than older workers, thus their risk of injury increases (Root and Hoefer, 1979; Siskind, 1982). This study highlights the statistically significant relationship between work experience and age ( $p$ value less than 0.001 in the independence test $\chi^{2}$ ). In this case, however, $95 \%$ of respondents under 25 did not have children and were therefore not subjected to work-family conflict; other factors were involved in the cause of these accidents (Laflamme and Menckel, 1995; Rhodes, 1983; Salminen, 1996, 2004), but these are not the subject of this study.

The results for the secondary objective, regarding the changes in the routine performance of household tasks during the leave period, showed that in $14 \%$ of cases, help came from the women's partners, who requested a temporary modification of their work schedules. In $24 \%$ of cases, children had to change their routine or live temporarily in the home of other family members while their mother was recovering. This lack of support from the partner is due to cultural reasons and to the inflexibility of men's work schedules (Kauppinene and Irja, 1998). Children's schedules and habits depend on the availability of women to coordinate them, to the point that when she finds it difficult to maintain the daily routine, the children's conditions are changed. Fourteen percent of the women had to ask for financial assistance in order to cover their household duties during their leave period after the accident. Five percent of the comments added by the respondents referred to the need for financial assistance during the time off work so that their families did not suffer a decline in their quality of life. In the case of accidents in itinere, the children of $12 \%$ of the women who considered that they had family-related stress had to change their family routine, as compared to $3 \%$ of the women who considered that they suffered stress, but whose accident occurred in the workplace. In these cases, the average leave time when the accident occurred in the workplace was 25 days, and when it occurred on the way to and from work, this average value rose to 46 days, which had a greater effect on the families.

As shown in Section 3, the injury leave times are fairly varied, but $38 \%$ of the women were off work for at least one month, and in $22 \%$ of cases the injury leave was prolonged for 2 months or longer. Moreover, $70 \%$ of the respondents indicated that they suffered from after-effects, although their seriousness was not described. There is no unified definition of what constitutes a minor work accident (Benavides and Serra, 2003); this depends on how it is classified by the doctor. Reclassifying the seriousness of work-related accidents by considering time off work - as in the Danish system in which serious injuries are predefined as losttime-injury incidents resulting in amputations, bone fractures, or multi-trauma injuries, and minor injuries include all other reported non-fatal lost-time-injury incidents (Kines \& Mikkelsen, 2003) would group work accidents in a more homogeneous manner, as it would consider type of injury and time off work.

\subsection{Limitations of the survey}

The application of the Data Protection Act required that the women selected should remain totally anonymous to the team carry- ing out the survey. Only those women who voluntarily chose to do so contacted the research team by telephone, which helped to clarify some questions and the objective of the study. Most people answered by regular post, and this on occasion could give rise to some ambiguity or uncertainty in the answers due to the peculiarities of specific cases; this could only have been avoided by personal interviews.

However, although the sampling errors were low, we believe the reason that only $13 \%$ of the 2400 women to whom the questionnaire was sent actually answered was the fact that it is always more laborious to answer a questionnaire in writing and send it by post than to answer by telephone. Another aspect highlighted by those who answered the questionnaire by telephone was the fear that the survey was being done by their employers. These women reported in the questionnaire that they had been threatened with dismissal or had suffered "mobbing" by the company after the accident, and believed that objective of the survey would in some way be detrimental to them, despite the fact that the subjects were informed that the aim of the study was to determine the aspects which should be better covered by future plans aimed at facilitating work-family combination.

\section{Conclusions}

Although the limitations of the study preclude the drawing of definitive conclusions, it provides some useful indications for a better understanding of the influence of the effort of combining work and family on minor work accidents. The first conclusion is that a high percentage of respondents, regardless of the economic sector involved or the educational level, were possibly suffering from work-family strain at the time of the accident. In these cases, the percentage of accidents was greater traveling to and from work than in the workplace itself.

The study also detected a lack of motivation by women in their work, and that this lack of motivation was, in the case of many respondents, related with the lack of compatibility between work and family life. This same lack of motivation is itself another risk factor.

The study shows that despite of polices, the degree of participation by men in family life remained low, and it remained low both before and after the accident. To prevent the risk of accidents in women and to improve their well-being, it is necessary to promote educational policies that change these cultural factors, and to encourage employers to support family life, in benefit of both women and men.

"Minor" accidents vary widely in seriousness and importance, and include those that may become a problem affecting the lives of women on many different levels. A more precise definition of minor work accidents in the Spanish legislation would facilitate their analysis and processing both by researchers and by the administration itself.

Finally, the study should be extended to men who have suffered minor work accidents in order to compare results - as well as to working women and men who have not suffered work accidents - in order to determine the degree of stress caused to women in their dual roles as workers and as the people who are primarily responsible for the family, and whether this stress has given rise to any risk situations.

\section{Acknowledgement}

This study is part of the project "Work accident and Balancing Work and Family" sponsored by the Institute for Health and Safety at Work of the Madrid Regional Government. 


\section{References}

Alhaique, D., 2000. Invecchiamento e infortuni sul lavoro. La Medicina del Lavoro $91,403-417$.

Allen, T.D., Herst, D.E.I., Bruck, C.S., Sutton, M., 2000. Consequences associated with work-family conflict: a review and a agenda for future research. Journal of Occupational Health Psychology 5, 278-308.

Attwood, D., Khan, F., Veitch, B., 2006. Occupational accident models - where have we been and where are we going? Journal of Loss Prevention in the Process Industries $19,664-682$.

Benavides, F.G., Serra, C., 2003. Evaluación de la calidad del sistema de información sobre lesiones por accidentes de trabajo en España. Archivo de Prevención de Riesgos Laborales 6, 26-30.

Biscay, V., 1999. Stress: ugly duckling or beautiful swan? Interact. Governor's Interagency Committee of State Employed Women (ICSEW). <http:// www.wa.gov/icsew> (accessed September 2007)

Bond, J., Galinsky, E., Swanberg, J., 1997. The 1997 National Study of the Changing Workforce. Families and Work Institute, New York.

Bureau of Labor Statistics, 2004. Standard occupational classification. US Department of Labor. <http://www.bls.gov/soc/socguide.htm> (accessed January 2008).

Burke, R.J., 1988. Some antecedents and consequences of work-family conflict. Journal of Social Behaviour Perspectives 3, 287-302.

Cea, M.A., 2001. Metodología cuantitativa. Estrategias y técnicas de investigación social, Síntesis, Madrid.

Conde, F., Gabriel, C., 2002. La evolución de las representaciones sociales sobre salud de las mujeres madrileñas, 1993-2000. Revista Española de Salud Pública 76, 493-507.

European Agency for Safety and Health at Work, 2000. The State of Occupational Safety and Health in the European Union-Pilot Study. Office for Official Publications of the European Communities, Luxembourg.

European Commission, 2002. Adapting to change in work and society: a new community strategy on health and safety at work 2002-2006. COM(2002) 118 . Brussels.

European Commission, 2006. The Social Situation in the European Union 20052006 Overview. Directorate-General for Employment, Social Affairs and Equal Opportunities, Eurostat.

Eurostat, 2005. Accidents at work: incidence rate. with more than three days' absence (per 100,000 persons employed) Statistics Office of the European Union. <http://epp.eurostat.ec.europa.eu> (accessed October 2005)

Galinsky, E., Bond, J., Friedman, D., 1993. The Changing Workforce: Highlights of the National Study. Families and Work Institute, New York.

Geurts, S.A., Rutte, C., Peeters, M., 1999. Antecedents and consequences of workhome interference among medical residents. Social Science and Medicine 48, $1135-1148$.

Grandey, A.A., Cropanzano, R., 1999. The conservation of resources model applied to work-family conflict and strain. Journal of Vocational Behavior 54, 350-370.

Greenhaus, J.H., 1988. The intersection of work and family roles: individual, interpersonal and organizational issues. Journal of Social Behavior and Personality 3, 23-44.

Greenhaus, J.H., Kopelman, R.E., 1981. Conflict between work and nonwork roles: Implications for the career planning process. Human Resource Planning 4, 1-10.

Greenhaus, J.H., Parasuraman, S., 1999. Research on work, family and gender: current status and future directions. In: Powell, G.N. (Ed.), Handbook of Gender in Organizations. Sage, Newbury Park, CA.

Hurrell, J., Murphy, L., 1992. Psychological job stress. In: Rom, W. (Ed.), Environmental and Occupational Medicine, second ed. Little, Brown, Boston, MA, pp. 675-684.

Instituto Nacional de Estadística, 1999. Encuesta de Fecundidad. <http:// www.ine.es/> (accessed August 2007).

Instituto Nacional de Estadística, 2005a. Accidentes de trabajo y enfermedades profesionales. Serie 1997-2004. <http://www.ine.es/inebase/cgi/axi> (accessed May 2005).

Instituto Nacional de Estadística, 2005b. Encuesta de Población Activa 2004. $<$ http://www.ine.es> (accessed May 2005)

Instituto Nacional de Estadística, 2006. Contabilidad Regional de España. Base 2000 $<$ http://www.ine.es/daco/daco42/cre00/cre0004.xls> (accessed October 2006).

Instituto Nacional de Estadística, 2007. Panel de hogares de la Unión Europea 2001. $<$ http://www.ine.es> (accessed September 2007)
Islam, S.S., Velilla, A.M., Doyle, E.J., Ducatman, A.M., 2001. Gender differences in work related injury/illness: analysis of workers compensation claims. American Journal of Industrial Medicine 39, 84-91.

Jacinto, C., Aspinwall, E., 2004. A survey on occupational accidents' reporting and registration systems in the European Union. Safety Science 42, 933960.

Jansen, N.W.H., Kant, I., Kristensen, T.S., Nijhuis, F., 2003. Antecedents and consequences of work-family conflict: a prospective cohort study. Journal of Occupational and Environmental Medicine 45, 479-491.

Kauppinene, K., Irja, K., 1998. Gender and Working Conditions in the European Union European Foundation for the Improvement of Living and Working Conditions, Dublin, Ireland.

Kines, P., Mikkelsen, L.K., 2003. Effects of firm size on risks and reporting of elevation fall injury in construction trades. Journal of Occupational and Environmental Medicine 45, 1074-1078.

Kirschenbaum, A., Oigenblick, L., Goldberg, A.l., 2000. Well being, work environment and work accidents. Social Science in Medicine 50, 631-639.

Laflamme, L., Menckel, E., 1995. Aging and occupational accidents. A review of the literature of the last three decades. Safety Science 21, 145-161.

Lankau, M.J., 1997. An examination of mentoring, peer developmental relationships, and team participation as sources of learning in an organization. Dissertation Abstracts International 57,5220A.

Lewis, S., Cooper, C.L., 1999. The work-family research agenda in changing contexts Journal of Occupational Health Psychology 4, 382-393.

Li, C.Y., Du, C.L., Chen, C.J., Sung, F.C., 1999. A registry-based case-control study of risk factors for the development of multiple non-fatal injuries on the job. Occupational Medicine 49, 331-334.

Lundberg, U., Frankenhaeuser, M., 1999. Stress and workload of men and women in high-ranking positions. Journal of Occupational Health Psychology 4, 142-151.

Martín, P., Vera, J.J., Cano, C., Molina, C., 2004. Nuevos retos de las políticas de salud laboral en las organizaciones de trabajo: una aproximación al estrés laboral y al "burnout" en clave psicosocial. Temas Laborales 75, 187-211.

Ministerio de Trabajo y Asuntos Sociales, 2004, Declaración electrónica de trabajadores accidentados. Parte de accidentes laborales. <https:// www delta.mtas.es> (accessed May 2005).

Petersen, D., 1984. Human-error Reduction and Safety Management. Aloray Inc. New York.

Pleck, J.H., Staines, G.L., Lang, L., 1980. Conflict between work and family life. Monthly Labor Review 103, 29-32.

Reich, R., Nussbaum, K., 1994. Working Women Count! A Report to the Nation. US. Department of Labor, Women's Bureau. Washington, DC.

Rhodes, S.R., 1983. Age-related differences in work attitudes and behavior: a review and conceptual analysis. Psychological Bulletin 93, 328-367.

Robinson, S., Kraatz, M., Rousseau, D., 1994. Changing obligations and the psychological contract: a longitudinal study. Academy of Management Journal 37, 137-152.

Root, N., Hoefer, M., 1979. The first work-injury data available from new BLS study. Monthly Labor Review 102, 76-80.

Salminen, S., 1996. Work-related accidents among young workers in Finland. International Journal of Occupational Safety and Ergonomics 2, 305-314.

Salminen, S., 2004. Have young workers more injuries than older ones? An international literature review. Journal of Safety Research 35, 513-521.

Sauter, S., Swanson, N., 1996. An ecological model of musculoskeletal disorders in office work. In: Moon, S., Sauter, S. (Eds.), Psychosocial Factors and Musculoskeletal Disorders in Office Work. Taylor and Francis, New York, NY pp. 3-21.

Siskind, F., 1982. Another look at the link between work injuries and job experience. Monthly Labor Review 105, 38-40.

Swaen, G.M.H., van Amelsvoort, L.P.G.M., Bultmann, U., Kant, I.J., 2003. Fatigue as a risk factor for being injured in an occupational accident: results from the Maastricht Cohort Study. Journal of Occupation and Environmental Medicine 60 (Suppl. I), i88-i92.

Swaen, G.M.H. van Amelsvoort, L.P.G.M., Bultmann, U., Slangen, JJ.M., Kant, IJ. 2004. Psychosocial work characteristics as risk factors for being injured in an occupational accident. Journal of Occupation and Environmental Medicine 46 , 521-527.

Swanson, N.G., 2000. Working women and stress. Journal of the American Medical Women's Association 55, 76-79. 